\title{
KONSEP DAN TANTANGAN DALAM IMPLEMENTASI TALENT MANAGEMENT DI PERUSAHAAN MULTINASIONAL: STUDI KASUS PT UNILEVER INDONESIA TBK
}

\author{
Ahmad Saomin Ali, Aji Hermawan, \& Yudha Heryawan Asnawi \\ Institut Pertanian Bogor \\ E-mail: a.saominali@gmail.com
}

\begin{abstract}
ABSTRAK
Tujuan dari penelitian ini yaitu menganalisis pemahaman responden terkait Talent Management (TM), konsep, praktik serta tantangan dalam menjalankan TM. Responden terdiri dari pemegang kepentingan (Professional HR, Senior eksekutif, line manajer) dan peserta TM. Penelitian ini mengadopsi pendekatan kualitatif dengan studi kasus di PT Unilever Indonesia Tbk sebagai perusahaan multinasional (MNC). Temuan dalam penelitian ini mengindikasikan bahwa implementasi TM akan tergantung kepada budaya, jenis perusahaan dan individu di sebuah perusahaan. Pemahaman dari konsep TM berbeda di setiap level. Praktik TM di PT Unilever Indonesia Tbk menggunakan pendekatan inclusive people. Program TM sudah cukup baik dan berhubungan dengan strategi jangka panjang. Namun, masih banyak yang harus diperbaiki dan praktik TM di PT Unilever Indonesia menekankan pada $70 \%$ pengalaman atau on the job assignment, $20 \%$ coaching dan mentoring, dan $10 \%$ pengembangan formal.
\end{abstract}

Kata kunci: talent, talent management, inclusive people, perusahaan multinasional, the war for talent

\begin{abstract}
The purpose of this study is to analyze the understanding responden of Talent Management (TM), concepts, practices and challenges in implementation of TM. Respondents consists of stakeholder(ProfessionalHR, Seniorexecutives, LineManagers) andTMparticipants. Qualitative approach is adopted in the study with case study atPTUnilever Indonesia Tbk as a multinational company (MNC). Findings in this study indicate that TM implementation will depend on the culture, type of company, and individual of the company. Understanding of the TM concept has different at each level. TM practices at PT Unilever Indonesia Tbk use the inclusive people approach. The TM program is good enough and synergizes with long-term business strategies; however, still has a lot of improvement, and practice of TM more on $70 \%$ experience or on the job assignment, $20 \%$ coaching and mentoring, and $10 \%$ formal development.
\end{abstract}

Keywords: talent, talent management, inclusive people, multinational company, the war for talent. 


\section{Ahmad Saomin Ali \\ Aji Hermawan \\ Yudha Heryawan Asnawi \\ PENDAHULUAN}

Talent Management (TM) menjadi topik yang banyak diperbincangkan dan mendapatkan minat yang luar biasa diantara para praktisi dan akademis semenjak konsultan dari McKinsey yaitu Chambers pada tahun 1998 memperkenalkan "The War for Talent" (Collings dan Mellahi, 2009). Penelitian dan publikasi akademis telah banyak, akan tetapi belum banyak melihat dari sisi aplikasi dalam konteks organisasi (Staunton, 2014). Selain itu, sebagian pakar menyatakan bahwa TM belum memiliki landasan definisi dan merupakan ilmu baru di dunia akademik serta tidak memiliki basis penelitian empiris untuk menguji ideide konseptual (Lewis dan Hechman, 2006; Staunton, 2014). Menurut Kabwe (2011) TM baik sebagai praktik maupun sub-disiplin akademik tidak memiliki landasan konseptual yang kuat. Oleh karena itu, TM menjadi hal yang menarik untuk dilakukan penelitian mengingat lingkungan bagi kebanyakan organisasi saat ini bersifat global, kompleks, dinamis, sangat kompetitif, cenderung sangat tidak stabil. Hal ini akan terus berlangsung untuk beberapa tahun ke depan. Hal ini juga akan sangat terasa terutama untuk perusahaan yang beroperasi secara global atau perusahaan multinasional (Tarique dan Schuler, 2009).

Menurut Capelli dan Keller (2014) TM merupakan proses mengantisipasi dan memenuhi kebutuhan organisasi terhadap bakat atau talent dalam pekerjaan yang strategis. TM merupakan praktik jangka panjang dengan tujuan menghasilkan orang yang tepat dalam pekerjaan yang tepat pada waktu yang tepat, TM meliputi perencanaan tenaga kerja, succession planning, pengembangan karyawan, dan manajemen karir (Cappelli dan Keller, 2014). Penelitian terkait praktik dan tantangan TM dalam berbagai konteks yang berbeda-beda telah dilakukan (misal Lewis dan Heckman, 2006; Chuai, Preece dan lles, 2008; Collings dan Mellahi, 2009; Collings, 2014; Cooke, Saini dan Wang, 2014; Staunton 2014). Studi perbandingan secara sistematis telah dilakukan untuk mengetahui dan memahami implementasi TM di PT Unilever Indonesia Tbk, yang meliputi sejauh mana para pemangkU kepentingan (Senior eksektutif, Line manajer dan Manajer Sumber Daya Manusia (SDM)) serta peserta TM memahami konsep TM, bagaimana praktik, tantangan dan hambatan dalam pelaksanaan TM serta peran SDM dalam TM.

Berdasarkan fenomena-fenomena di atas, terdapat empat alasan utama dilakukannya penelitian ini. Pertama, Unilever merupakan perusahaan multinasional (MNC) di Indonesia yang bergerak secara global. Pada akhir tahun 2016, saham Perseroan menempati peringkat ke-lima kapitalisasi pasar terbesar di Bursa Efek Indonesia, dengan 6000 karyawan di Indonesia dan lebih dari 400 merek yang dibeli di 190 negara. Kedua, peran Departemen SDM di perusahaan multinasional dalam mengelola karyawan Unilever bertujuan untuk mencapai seluruh potensi mereka melalui peningkatan keseimbangan hidup, dan pembangunan kemampuan karyawan, karena menurutnya hanya dengan cara inilah Unilever dapat meningkatkan potensi bisnis. Ketiga, banyaknya asumsi yang dibuat oleh para peneliti tentang TM sehingga sulit menemukan makna yang tepat terkait TM serta masih belum banyak yang melihat dari sisi aplikasi dalam konteks organisasi, terutama di Indonesia. Keempat, TM merupakan bidang SDM yang tergolong muda, penelitian tentang TM sebagai ambiguitas konseptual dalam hal siapa individu yang disebut talent, apa yang dianggap strategis, dan apa arti dari TM masih diperdebatkan. Pada praktiknya, masih banyaknya organisasi yang mengikuti TM tanpa pandangan yang jelas tentang siapa talent itu dan bagaimana TM harus dioperasionalkan dalam konteks organisasi yang lebih spesifik (Cooke, Saini dan Wang, 2014).

MNC menjadi bahan studi kasus karena tiga alas an. Pertama, pengakuan bahwa manajer yang memiliki kompetensi secara internasional mewakili komponen kunci keberhasilan sebuah perusahaan. Kedua, semakin sulitnya menemukan dan mempertahankan talent manajerial yang sesuai untuk mengelola perusahaan sedangkan perusahaan internasional dan pertumbuhan pasar negara berkembang semakin meningkat. Ketiga, tuntutan 
keterampilan yang dibutuhkan perusahaan MNC lebih kompleks dari perusahaan lokal (McDonnell, Lamare, Gunningle, dan Lavelle, 2010). Menurut Tarique dan Schuler (2009) keakuratan diagnosa dari situasi TM di MNC adalah awal dari keberhasilan dalam menerapkan TM yang benar untuk mendapatkan dan mempertahankan keunggulan kompetitif global, alasan lainnya para peneliti mengakui bahwa kegiatan Human Resource Management (HRM) yang efektif dari MNC menyebabkan peningkatan kinerja organisasi baik itu jangka pendek maupun jangka panjang. Namun, "efektivitas" merupakan bidang "yang paling sedikit dipelajari" dari TM (Tarique dan Schuler, 2009). Penelitian terkait TM telah banyak dilakukan di negara-negara besar dengan jenis perusahaan MNC (misal Staunton, 2014; lles, Chuai dan Preece, 2010; Lamare, Gunningle, dan Lavelle, 2010; Tafti, Mahmoudsalehi, dan Amiri, 2016), meski ada penelitian yang dilakukan selain di perusahaan MNC seperti yang dilakukan oleh Cooke, Saini dan Wang (2014).

Penelitian ini bertujuan untuk mengetahui bagaimana kelompok pemangku kepentingan (Professional SDM, Senior eksekutif, Line Manajer) dan peserta Talent Management dalam memahami konsep TM dan mengetahui bagaimana praktik dan tantangan dalam menjalankan TM di PT Unilever Indonesia Tbk.

\section{LANDASAN TEORI}

Banyak perusahaan yang mengatakan bahwa karyawan adalah asset paling berharga bagi perusahaan, tapi faktanya tidak banyak perusahaan yang sungguh-sungguh menilai orang-orang yang terdapat dalam organisasi sebagai asset terpenting mereka yang mampu memberi pengaruh terbesar dalam kelangsungan sebuah organisasi. Kenyataan tersebut menjadikan strategi dalam pengelolaan Sumber Daya Manusia (SDM) sebagai salah satu hal penting, dan perlu dirancang sebaik mungkin sehingga mampu menciptakan para pelaku bisnis yang kompeten serta dapat bertahan dalam organisasi. Komitmen dan dasar bekerja sebuah perusahaan akan tercermin dari budaya perusahaan itu sendiri (Chen, 2015). Konsep budaya perusahaan telah tertanam dan menjadi pemikiran di bidang manajemen dan studi tentang budaya perusahaan atau organisasi telah berkembang lebih dari enam dekade yang lalu (Chen, 2015).

Budaya organisasi merupakan seperangkat nilai, kepercayaan, dan norma di dalam sebuah organisasi yang memengaruhi pikiran dan tindakan karyawan (Flamholtz dan Randle, 2012), sehingga memiliki dampak yang besar pada harga diri orang, efektivitas, kesehatan mental (Doran dan Littrell, 2013) produktivitas dan kesejahteraan karyawan (Chen, 2015). Webber dan Tabra (2012) telah merangkum tujuh dimensi budaya organisasi, yaitu pendekatan organisasi untuk inovasi dan aktivitas, pendekatan untuk manajer pengambilan risiko, saling ketergantungan lateral, kontak manajemen puncak dan dukungan bawahan, budaya otonomi dan pengambilan keputusan, orientasi organisasi untuk kinerja, dan orientasi menuju penghargaan. Budaya organisasi memiliki dampak signifikan terhadap keberhasilan sebuah organisasi serta mampu membentuk perilaku dan kinerja dalam organisasi (Idowu, 2017). Fey dan Denison (2003) menyatakan bahwa budaya organisasi mempengaruhi banyak aspek kinerja organisasi, diantaranya yaitu kinerja keuangan, inovasi, kepuasan pelanggan dan karyawan. Lee dan Yu (2004) mengatakan bahwa kekuatan budaya organisasi akan menjadi sumber keunggulan kompetitif dan berdampak pada kinerja organisasi. Divakaran (2012) menyatakan budaya yang kuat, merek dan proporsi nilai karyawan sangat penting untuk menarik dan mempertahankan karyawan bertalenta dalam perusahaan, dengan perekrutan yang lebih efektif, tingkat kepuasan karyawan lebih tinggi dan lebih terlibat, sehingga tingkat karyawan meninggalkan perusahaan lebih rendah dan kontrol upah yang lebih baik.

Istilah "the war for talent" menjadi bidang yang sangat popular dan berkembang pesat setelah Chamber seorang konsultan dari McKinsey pada tahun 1998 memperkenalkannya 


\section{Ahmad Saomin Ali \\ Aji Hermawan \\ Yudha Heryawan Asnawi}

(Xue 2014). Talent banyak diartikan dengan menggabungkan istilah kualitas dan kegiatan, sehingga Davis et al. (2007) mengartikan talent sebagai bakat atau keahlian tertentu yang dimiliki oleh seseorang, lles (2013) berpendapat bahwa talent adalah kemampuan alami (bawaan, kemampuan unik) seseorang dan sebagai penguasaan (keterampilan dan pengetahuan yang dikembangkan secara sistematis). Pendapat lain disampaikan oleh Tansley (2011) yang mengatakan bahwa talent bukan kemampuan bawaan akan tetapi dapat diperoleh dan dikembangkan sehingga talent dapatmendorong bisnis dimasa depan.

MNC menyadari perlunya pengelolaan tenaga kerja secara efektif untuk mendapatkan keunggulan kompetitif global yang berkelanjutan (Tarique dan Schuler, 2009). Menurut Xue (2014) MNC mengutamakan pencarian talent dengan kategori top talent, menuntut pengembangan karir, tempat kerja yang beragam dan pekerjaan yang menginspirasi dan kompensasi yang baik. Tarique dan Schuler (2009) MNC harus mengembangkan reputasi SDM dan daya tarik organisasi, serta mengidentifikasi talent pool yang tepat untuk menarik talent yang mereka butuhkan. Baum dan Kabst (2013) menemukan adanya perbedaan lintas negara tertentu dari segi pandangan karyawan, khususnya daya tarik tugas dari pekerjaan. Berdasarkan perspektif karir, pengembangan pribadi dan menumbuhkan suasan kerja yang positif merupakan penting bagi karyawan dari negara yang dijadikan sampel. Gaji tidak terlalu berpengaruh di semua negara yang dijadikan sebagai sampel. Berdasarkan hal di atas Baum dan Kabst (2013) memberikan rekomendasi bahwa MNC harus mengadopsi pendekatan posisioning yang umum di seluruh dunia, sehingga kegiatan branding MNC dapat dikoordinasikan pada skala internasional. Mencari orang dengan keterampilan yang tepat untuk posisi yang sesuai merupakan definisi umum dari TM dan merupakan tantangan untuk manajemen SDM pada organisasi apapun. Definisi lain dari TM adalah proses yang digunakan perusahaan untuk mengantisipasi dan memenuhi kebutuhan human capital (HC) mereka (Cappelli 2008).

Menurut lles et al. (2010) terdapat empat perspektif pada pelaku TM: Pertama, exclusivepeople (lles et al. 2010, Preece et al. 2011) dalam hal ini memandang talent dengan relative sempit yaitu hanya orang-orang yang memiliki kemampuan untuk membawa perubahan yang signifikan bagi organisasi baik sekarang maupun masa yang akan datang. Hal ini mengadopsi pernyataan bahwa TM adalah HRM dengan fokus selektif. Kedua, exclusive-positions, dalam hal ini organisasi yang berfokus pada posisi kunci dalam organisasi, menganggap bahwa titik awal TM adalah mengidentifikasi pekerjaan strategis. Orang-orang yang menempati posisi tersebut dianggap sebagai talent, sehingga menempatkan karyawan terbaik di posisi strategis. Ketiga, inclusive-people berpotensi menjadikan setiap orang yang berada dalam organisasi dianggap memiliki talent. Mereka bertugas mengelola semua karyawan untuk memberikan kinerja tinggi. Hal ini menegaskan bahwa setiap orang memiliki peran dalam organisasi. Keempat yaitu Social Capital, yang dalam perspekif ini organisasi harus berfokus pada peningkatan talent secara internal dan mempertahankan bintang-bintang yang muncul. Hal ini karena faktor spesifik perusahaan berdampak pada kesuksesan talent, termasuk sumber daya dan kemampuan, sistem dan proses, kepemimpinan, jaringan internal, pelatihan dan keanggotaan tim.

\section{METODE}

Penelitian dilakukan dengan metode kualitatif untuk memahami praktik TM secara lebih mendalam. Studi kasus yang digunakan dalam penelitian adalah PT Unilever Indonesia Tbk. Penelitian yang dilakukan oleh lles at al. (2010), Preece at al. (2011), dan McDonell at al. (2010) hanya memiliki jumlah responden yang kecil (Cooke at al., 2014). Meski begitu, penelitian studi kasus merupakan "studi mendalam tentang suatu kasus" yang menghasilkan tema dan deskripsi rinci mengenai kasus tersebut (Chuai, 2008). Desain penelitian ini menggunakan metode deskriptif. Menurut Morissan (2014) metode deskriptif merupakan penelitian ilmiah yang dilakukan secara hati-hati dan cermat, oleh karenanya lebih akurat dan tepat. 
Data yang diperoleh dalam penelitian ini merupakan data primer dan data sekunder. Data primer diperoleh dari wawancara semi terstruktur dan observasi langsung. Data sekunder diperoleh dan diolah dengan mengakses informasi, data dan studi literatur menggunakan review dokumen, buku, internet, artikel ilmiah, dan data-data lain yang relevan dengan penelitian ini. Teknik pengambilan sampel adalah metode non-profitability sampling jenis purposeful sampling, jenis strategi sampling yang bersifat homogenous sampling (Herdiansyah, 2010). Responden terdiri dari pemangku kepentingan (professional HR, Senior Eksekutif dan Line Manajer) dan peserta TM (Tabel 1).

Tabel 1.

Sampel Penelitian Implementasi Talent Management di PT Unilever Indonesia Tbk

\begin{tabular}{|c|c|c|c|c|}
\hline $\begin{array}{l}\text { Kode } \\
\text { Subjek }\end{array}$ & Nama Subjek & Masa Jabatan & Function & Business Title \\
\hline SE 1 & Senior Eksekutif & Lebih dari 10 tahun & Supply Chain & Direktur Plant 1 \\
\hline SE 2 & Senior Eksekutif & $5-10$ tahun & Supply Chain & Direktur Plant 2 \\
\hline $\mathrm{HR}$ & $\begin{array}{c}\text { Sumber Daya } \\
\text { Manusia }\end{array}$ & Lebih dari 5 tahun & Supply Chain & Manajer SDM \\
\hline LM 1 & Line Manajer & Lebih dari 10 tahun & Supply Chain & Line Manajer 1 \\
\hline LM 2 & Line Manajer & $5-10$ tahun & Supply Chain & Line Manajer 2 \\
\hline PTM 1 & $\begin{array}{l}\text { Peserta Talent } \\
\text { Management }\end{array}$ & Lebih dari 10 tahun & Supply Chain & Asisten Manajer 1 \\
\hline PTM 2 & $\begin{array}{c}\text { Peserta Talent } \\
\text { Management }\end{array}$ & 5 - 10 tahun & Supply Chain & Asisten Manajer 2 \\
\hline PTM 3 & $\begin{array}{l}\text { Peserta Talent } \\
\text { Management }\end{array}$ & $1-5$ tahun & Supply Chain & Asisten Manajer 3 \\
\hline PTM 4 & $\begin{array}{c}\text { Peserta Talent } \\
\text { Management }\end{array}$ & $0-1$ tahun & Supply Chain & Asisten Manajer 4 \\
\hline
\end{tabular}

Pemilihan sampel dilakukan karena mereka dapat memberikan perspektif tertentu pada fenomena yang sedang dipelajari (Staunton, 2014). Staunton (2014) berpendapat bahwa empat dan sepuluh wawancara dianggap cukup, tergantung pada keadaan. Silzer dan Dowell (2010) dan Staunton (2014) mengusulkan tiga kelompok untuk penelitian yang terdiri dari senior eksekutif, line manajer dan praktisi SDM. Penelitian ini fokus pada Function Supply Chain (Gambar 1), karena 76,37\% karyawan berada pada function tersebut.

Penelitian ini menggunakan teknik pengolahan dan analisis data melalui empat tahap yang terdiri dati tahap pertama, mencatat semua hasil wawancara yang telah di rekam. Tahap kedua, review kembali hasil transkripsi dan mengirimkan kembali hasil pencatatan kepada peserta wawancara beserta dengan rekaman yang telah dilakukan, serta melakukan pengajuan persetujuan hasil wawancara. Tahap ketiga, identifikasi hasil wawancara dengan data yang relevan dan melakukan sorting data hasil wawancara. Terakhir, interpretasi data atau hasil wawancara dan menjelaskan lebih mendalam berdasarkan hasil wawancara dengan para peserta.

\section{HASIL DAN DISKUSI}

\section{Budaya Perusahaan}

Menghadapi persaingan bisnis yang bersifat global, yang membedakan satu perusahaan dengan perusahaan lain adalah penerapan nilai atau budaya perusahaan dalam menjalankan bisnisnya. Budaya yang baik akan mampu menghadapi perubahan dan membawa hasil yang optimal. Unilever memiliki tujuan, nilai dan prinsip yang dijunjung tinggi dalam menjalankan operasi bisnis. Unilever berprinsip, untuk bisa sukses dalam hal bisnis, perlu standar perilaku perusahaan yang tinggi terhadap karyawan, masyarakat yang 


\section{Ahmad Saomin Ali \\ Aji Hermawan \\ Yudha Heryawan Asnawi}

terlibat, dan lingkungan yang menerima dampak. Unilever bekerja dengan integritas, yang artinya melakukan bisnis dengan integritas dan hormat terhadap banyak orang, organisasi, dan lingkungan. Komponen-komponen tersebut menjadi inti dari tanggung jawab perusahaan. Tujuan ini juga didukung oleh Kode Etik Prinsip Bisnis (CoBP) yang menjelaskan standar operasional yang diikuti oleh semua karywan Unilever di dunia. CoBP merupakan penjelasan sederhana tentang etika Unilever dalam beroperasi.

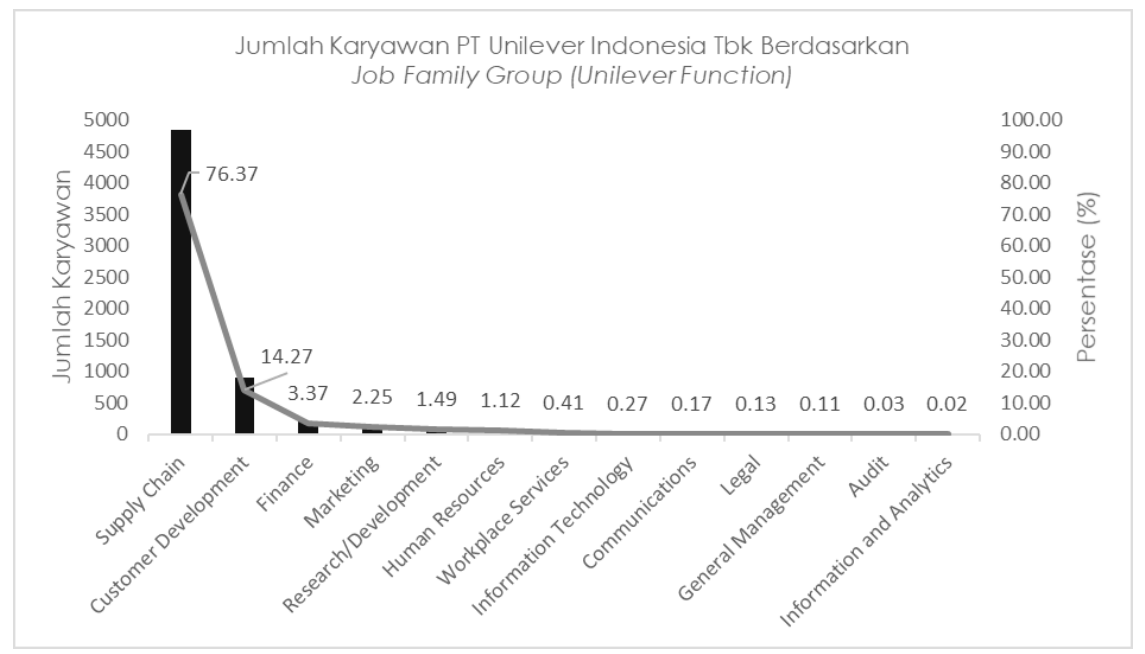

Gambar 1.

Jumlah karyawan PT Unilever Indonesia Tbk berdasarkan job family group (Unilever Function)

Pedoman ini diinformasikan kepada pihak eksternal dengan harapan semua pihak yang bekerja sama dengan Unilever dapat menerapkan prinsip tersebut dengan standar yang sama tingginya. Kebijakan-kebijakan pedoman menetapkan perilaku-perilaku etis yang perlu diterapkan sebagai karyawan Unilever. Unilever berkomitmen penuh terhadap karyawan dalam menjalankan bisnisnya karena Karyawan sebagai aset penting bagi perusahaan. Selain itu, sebagai MNC harus mampu membawa budaya organisasi dan tentunya harus mampu beradaptasi dengan budaya lokal dimana perusahaan itu bergerak. Unilever memiliki budaya perusahaan yang fokus pada karyawan melalui program TM. Berdasarkan hasil wawancara responden menyatakan bahwa langkah yang dilakukan perusahaan dalam melaksanakan TM ini sudah selaras dengan strategi bisnis. Strategi tersebut terdiri dari pengembangan kapabilitas sesuai dengan kebutuhan bisnis, digitalisasi 5.0, data personalisasi, dan kebutuhan konsumen, sehingga perusahaan dapat mempersiapkan para pemimpin masa depan yang memiliki kemampuan yang mumpuni dan memahami hal-hal tersebut.

Hal tersebut menunjukkan bahwa TM ini mendapatkan dukungan penuh dari perusahaan, meski para responden menyatakan bahwa TM ini masih perlu perbaikan. Perusahaan harus mampu mengakselerasi karyawan agar dapat selaras dengan strategi bisnis. Perusahaan dapat memperoleh keuntungan meskipun hanya memiliki sedikit karyawan karena mereka memiliki kapabilitias yang bagus. Hal ini sejalan dengan hasil penelitian Staunton (2014) mengenai perlunya mengubah budaya yang cocok dengan bisnis. Budaya perusahaan menjadi salah satu daya tarik seorang karyawan untuk bergabung dengan Unilever, seperti yang disampaikan oleh PTM 4:

"Unilever merupakan FMCG terbaik serta multinational company dengan background, tujuan dan arah yang jelas. Dengan background tersebut Unilever tentu mengandalkan bisnis, agar bisnis growth maka support produk harus bagus".

Hal ini sejalan dengan penelitian Divakaran (2012) yang menyatakan bahwa budaya perusahaan dapat menarik dan mempertahankan talent agar tetap berada dalam perusahaan. Hal ini menunjukkan bahwa sebuah budaya organisasi sangat penting bagi 
perusahaan (Divakaran, 2012) maupun jasa (Staunton, 2014) demi terlaksananya sebuah program TM. Hal ini menunjukkan bahwa perubahan budaya organisasi sangat diperlukan dalam semua organisasi. Perubahan budaya tersebut juga harus disertai dukungan dari perusahaan.

\section{Pemahaman Tentang Definisi Talent Management}

Menurut para responden TM merupakan pemahaman pribadi (Tabel 2). Responden belum mengetahui definisi resmi TM Unilever. Definisi resmi TM dari PT Unilever Indonesia Tbk adalah sebuah sistematis untuk menarik, identifikasi, pengembangan, mempertahankan dan penyebaran individu-individu yang memiliki nilai tertentu untuk organisasi, baik karena "high-potential" untuk masa depan atau karena mereka memenuhi peran bisnis atau posisi penting. Merujuk pada definisi resmi tersebut, hasil wawancara menunjukkan data yang sangat bervariasi. Definisi tersebut berlandaskan pada pengetahuan pribadi dari responden. Melihat banyaknya variasi ini tentu menjadi pekerjaan kedepannya untuk para pelaku SDM dalam memperkenalkan definisi resmi ini. Berdasarkan hasil wawancara, peneliti mencoba menguraikan bahwa TM merupakan program sistematis dalam mengembangkan karyawan untuk menjadi pemimpin sehingga mampu memberikan kontribusi untuk perusahaan baik itu jangka pendek maupun jangka panjang.

Definisi TM berdasarkan pemahaman dan praktik yang dilakukan saat ini merupakan sebuah program atau wadah untuk memberikan kesempatan kepada seluruh karyawan dalam membangun dan mengembangkan kemampuan mereka. Hal ini bertujuan agar karyawan mampu memberikan kontribusi yang selaras dengan pertumbuhan bisnis untuk mencapai tujuan dari perusahaan itu sendiri.

Penemuan ini sejalan dengan penemuan Chuai (2008) yang menyebutkan bahwa terdapat ketidakjelasan mengenai definisi dan ruang lingkup TM. Hal ini cukup mengganggu dan hal ini terjadi selama wawancara. Staunton (2014) dalam penelitian yang dilakukannya menemukan banyaknya perbedaan persepsi mengenai definisi TM. Konsep TM sulit didefinisikan karena banyak kegiatan yang dapat dimasukan di bawah istilah ini. Hasil penelitianmengungkapkanbahwaselaluadabakatyang belum ditemukandalamorganisasi.

Hal ini menunjukkan bahwa perlu ada sebuah kegiatan yang lebih mendalam dan pendekatkan antara departemen SDM dan karyawan, sehingga memberikan kesadaran akan adanya program TM ini. Meskipun pada dasarnya program TM ini adalah tugas para LM secara operasional, akan tetapi perkenalan dari departemen SDM masih sangat diperlukan di awal perkembangan program TM. Hal ini bertujuan agar tumbuh kesadaran yang tinggi. Hasil dari program TM juga akan memberikan dampak besar bagi perusahaan sejalan dengan strategi bisnisnya.

\section{Pemahaman Tentang Konsep Talent Management}

Bagi Unilever TM bukan suatu program atau konsep baru. Tantangan dan perubahan bisnis menuntut adanya perubahan pada konsep TM, sehingga akan banyak mengalami perubahan. Program yang saat ini dinilai baik, beberapa tahun ke depan mungkin sudah tidak relevan. Hal ini menunjukkan bahwa program dan praktik TM sesuai dengan bisnis yang saat ini berjalan. Unilever merupakan perusahaan yang memberikan kesempatan dan melihat bahwa semua karyawan merupakan talent dan harus dikembangkan.

Hal ini menunjukkan bahwa perusahaan tidak membeda-bedakan karyawan dalam mendapatkan hak pengembangan. Perusahaan harus mampu menangkap aspirasi dan harapan karyawan dengan baik yang disesuaikan dengan kemampuan yang dimiliki saat ini, sehingga perusahaan mengetahui pengembangan yang perlu dilakukan untuk mencapai harapan tersebut. Label bakat seperti "Hi-Po", "green boxer" sudah tidak lagi 


\section{Ahmad Saomin Ali \\ Aji Hermawan \\ Yudha Heryawan Asnawi}

digunakan. Pelabelan ini dinilai sebagai proses yang kaku. Perusahaan menilai proses pelabelan ini menghabiskan terlalu banyak waktu untuk melakukan diskusi dibandingkan dengan mengidentifikasi kebutuhan atau potensi pengembangan karyawan, sehingga saat ini perusahaan lebih fokus pada apa yang bisa mereka lakukan.

Tabel 2.

Definisi Talent Management Menurut Responden

\begin{tabular}{|c|c|}
\hline $\begin{array}{l}\text { Kode } \\
\text { Subjek }\end{array}$ & Definisi Talent Management \\
\hline $\mathrm{HR}$ & $\begin{array}{l}\text { Praktek TM Unilever dengan prinsip terbaru ini diartikan sebagai kebijakan } \\
\text { perusahaan yang tidak membeda-bedakan karyawan. Semua karyawan } \\
\text { dianggap sebagai talent dan harus dikembangkan dengan unik } \\
\text { dikarenakan setiap karyawan memiliki kekuatan dan kekurangan masing- } \\
\text { masing. Prinsip terdahulu TM hanya berfokus pada karyawan high-potensial, } \\
\text { sedangkan prinsip terbaru ini juga mengharuskan setiap karyawan memiliki } \\
\text { tujuan hidup selain tujuan karirnya dan kedua tujuan ini harus berjalan, } \\
\text { sehingga dengan bekerja di Unilever merupakan salah satu cara untuk } \\
\text { mencapai tujuan tersebut. }\end{array}$ \\
\hline
\end{tabular}

Company mampu maju karena memiliki good people. Company memiliki sistem dan infrastruktur tapi perlu ada dukungan dari human resource atau people yang mumpuni.

Unilever memiliki program untuk development baik karyawan staff (manajemen) maupun non-staff, ada proses untuk development dan ada juga jenjang karir yang dilalui oleh karyawan tertentu. TM itu bagian dari proses untuk mendevelop orang atau karyawan bagaimana dia bisa

SE 2 berkembang lebih baik lagi sejalan juga dengan pertumbuhan bisnis dan tentunya kita berharap mereka akan menjadi para leader di perusahaan. TM itu bagian dari proses untuk mendevelop orang atau karyawan bagaimana dia bisa berkembang lebih baik lagi sejalan juga dengan pertumbuhan bisnis dan tentunya kita berharap mereka kemudian akan menjadi para leader di perusahaan.

Ada definisi resmi terkait TM. TM merupakan program untuk mendevelop

LM 1 orang sehingga mampu membawa perusahaan mencapai strategi jangka panjang.

Unilever belum punya definisi yang baku. Akan tetapi, Unilever sudah punya culture sendiri yang on-going dan dinamis. Semua proses berjalan sampai saat ini. Akan tetapi meski begitu definisi TM tidak didefinisikan seperti itu. Inti

LM 2 dari TM adalah Unilever punya ambisi yaitu menjadi company 76 T Rupiah di 2022, targetnya doubling business terus menerus. Untuk mencapai itu tidak mungkin perusahaan tidak punya program TM. Apa yang dilakukan Unilever yaitu mempersiapkan apakah company siap menghadapi tantangan kedepannya untuk mencapai vision tersebut.

PTM 1 TM merupakan sebuah program pengembangan setiap individu.

HR tidak menjelaskan detail terkait Talent Management, akan tetapi ada pengembangan karir dan harapan karir yang disebut dengan Individual

PTM 2 Development Plan (Short term, Medium Term, Long Term) dan disediakan mentor. Akan tetapi, menurut saya Talent Management merupakan sebuah wadah untuk membahas perjalanan karir seseorang.

Belum mengetahui definisi yang secara pasti, hanya menangkap dari

PTM 3 nama TM itu sendiri bahwa TM adalah suatu sistem atau wadah yang membangun atau mengembangkan kemampuan karyawan sehingga mampu memberikan kontribusi untuk perusahaan.

TM merupakan sebuah program seperti Future Leader yaitu disiapkan jadi

PTM 4 leader tergantung dari kemampuan kita sendiri, seberapa mampu kita jadi leader dan seberapa lama kita menjadi leader. 
Tujuan utama TM di PT Unilever Indonesia Tbk yaitu fokus pada semua orang, mendorong perubahan budaya yang signifikan, menggerakkan karyawan agar fokus pada tujuan, pembelajaran, kesejahteraan dan penghargaan. Prinsip Utama TM adalah bagaimana karyawan mampu menemukan tujuan, kinerja, potensi dan rencana. Konsep utama TM diantaranya:

1. Availability yaitu seorang talent dapat dikatakan available apabila mereka dapat keluar dari peran saat ini dalam 3-6-9 bulan ke depan,

2. Promotability yaitu seseorang dikatakan promotable adalah peran berikutnya dari individu harus berada pada tingkat tanggung jawab yang lebih tinggi.,

3. Succesion Talent Pool, seorang karyawan dapat dikatakan "available" atau "promotable" berdasarkan diskusi para petinggi melalui sebuah forum

4. Casting, pencocokan antara tujuan individu, aspirasi, kemampuan, ketersediaan, dan potensi untuk posisi yang spesifik, dan mereka dapat berpindah dalam 3-9 bulan kedepan.

5. Business Challenge Talent Pools, Mengelompokkan talent dengan karakteristik spesifik terhadap tantangan bisnis spesifik untuk dikembangkan dengan tujuan memperkuat posisi tersebut.

6. Potential for What, menjelaskan peran apa yang dicita-citakan, tergantung dari preferensi individu, tujuan, pengalaman dan keahlian.

Praktik TM yang menjadikan setiap orang yang berada di organisasi memiliki talent atau disebut dengan istilah inclusive people, telah berjalan sejak akhir tahun 2016. Hal ini seperti yang disampaikan oleh Swailes, Downs, dan Orr (2014) yang mengemukakan bahwa strategi TM inklusif merupakan sebuah pengakuan bahwa semua karyawan memiliki bakat. Menurut Savaneviciene dan Vilciaukaite (2017) pada penelitiannya menemukan bahwa perusahaan besar lebih memilih strategi TM inklusif daripada ekslusif. Strategi inklusif mendominasi di perusahaan manufaktur, perbankan, katering, konsultasi, perdagangan, energi, transportasi, dan industri agribisnis. Berdasarkan penelitiannya, strategi TM inklusif menanggapi prinsip-prinsip yang berorientasi pengembangan potensi manusia dan merupakan pesan penting untuk menyusun lebih lanjut TM berdasarkan penggunaan potensi internal. Sedangkan perusahaan konstruksi menggunakan strategi TM eksklusif. Perusahaan IT lebih banyak menggunakan strategi TM yang beragam (menggunakan eksklusif dan inklusif).

Pendapat berdeda datang dari Chuai at al. (2008) yang mengatakan bahwa TM merupakan sebuah wadah yang meliputi fokus dan strategi kegiatan dalam manajemen orang dengan "menempatkan orang yang tepat diposisi yang tepat". HRM difokuskan pada "manajemen semua karyawan" di seluruh perusahaan sedangkan TM menargetkan "orang yang paling berharga dalam organisasi". Chuai at al. (2008) berpendapat bahwa fokus kepada keterampilan umum adalah salah satu bentuk dari HRM, sedangkan TM fokus yang ditargetkan pada karyawan dengan keterampilan spesifik. Perusahaan dianggap paling berharga untuk pengiriman proyek yang sukses yang dirancang untuk memenuhi kebutuhan klien atau perusahaan. Sedangkan Wilson (2015) berpendapat bahwa TM berfokus pada orang yang High Potential sehingga orang tersebut akan memberikan kontribusi bagi perusahaan.

Menurut Savaneviciene dan Vilciaukaite (2017), strategi yang sangat cocok untuk satu perusahaan belum tentu cocok untuk perusahaan yang lain. Oleh karena itu, memilih strategi TM harus spesifik, tidak hanya menilai kekuatan dan kelemahan dari setiap strategi, tapi juga berdasarkan faktor-faktor kontekstual seperti ukuran organisasi, budaya, nilai, misi dan strategi. Selain itu, penting untuk mengevaluasi strategi TM tidak hanya dalam konteks organisasi atau perusahaan tapi juga dalam konteks industri, atau bahkan konteks nasional. 


\section{Ahmad Saomin Ali \\ Aji Hermawan \\ Yudha Heryawan Asnawi}

Perbedaan dapat terlihat jelas menurut beberapa penelitian sebelumnya. Perbedaan ini mungkin terjadi karena adanya perbedaan sampel perusahaan yang digunakan, meski sama-sama perusahaan multinasional (MNC). Penelitian Chuai at al. (2008) menggunakan sampel perusahaan MNC dengan fokus pada perusahaan information technology (IT), health care, serta sektor pendidikan. Wilson (2015) fokus pada perusahaan jasa professional, sedangkan penelitian ini fokus pada MNC yang bergerak pada bidang manufaktur. Perbedaan hasil kemungkinan dikarenakan adanya perbedaan jenis dari perusahaan itu sendiri. Perbedaan hasil juga bisa diakibatkan oleh budaya perusahaan yang berbeda. Meskipun pada penelitian sebelumnya tidak dibahas mengenai budaya perusahaan, akan tetapi budaya perusahaan yang berbeda tentu akan memberikan hasil yang berbeda. Meski begitu, semua berpendapat sama bahwa TM berfokus pada bagaimana pengembangan karyawan sehingga mencapai kemampuan optimal dan memberikan hasil yang optimal bagi perusahaan.

\section{Praktik Talent Management}

\section{Mengapa Talent Management Penting?}

TM merupakan sebuah pendekatan dalam mengelola karyawan untuk memenuhi tujuan perusahaan baik dalam jangka pendek maupun jangka panjang. Praktik TM ini memerlukan waktu dan biaya yang tidak sedikit. Perlu adanya dukungan dari seluruh jajaran perusahaan agar tujuan dapat berjalan dengan optimal. Perusahaan perlu melakukan pengembangan karyawan, sebagai aset penting, penggerak sistem dan pembawa perubahan.

Wawancara dengan SE 1:

"Company mampu maju karena memiliki good people. Company memiliki sistem dan infrastruktur tapi perlu ada dukungan dari human resource atau orang yang mumpuni. Mumpuni dalam hal ini yaitu 1) Kemampuan adapting changes, dimana Unilever sebagai FMCG dan dunia berubah dengan eksponansial seperti teknologi, digitalisasi dan banyak disruptive, sehingga orang harus selalu bisa beradaptasi. 2) Mampu berinovasi dan kreatif, sehingga company bisa mendapat pleading dari market. Apabila kita mengetahui adanya trend perubahan, kita harus innovate our selve. Unilever mampu leading dari perusahaan lain. 3) Basic understanding yang berlaku di Unilever, misal operation excellence suatu pabrik atau marketing. 4) Motivasi, setiap orang harus memiliki motivasi, ingin maju, karir dan memiliki pengetahuan".

Unilever merupakan perusahaan yang memiliki ambisi besar untuk terus tumbuh lebih besar di masa mendatang, perusahaan ini tidak hanya mendahulukan transaksional akan tetapi perusahaan menganggap karyawan adalah aset penting yang harus dikembangkan dan dijaga. Selain itu perusahaan telah berpikir lebih jauh untuk tantangan yang akan dihadapi pada masa mendatang sehingga dipersiapkan lebih cepat untuk menjawab tantangan tersebut (LM 2). TM sangat penting bagi perusahaan untuk menciptakan karyawan yang mumpuni, yang mampu bersaing baik secara nasional maupun secara global (SE 2).

\section{Membangun Program TM Melalui Strategi Bisnis}

Program TM yang baik adalah program yang mampu selaras dengan strategi bisnis. Untuk mampu selaras dengan strategi bisnis, tentu harus dilihat dari segala aspek yang akan saling mempengaruhi. Salah satu tindakan yang saat ini dilakukan adalah bagaimana perusahaan mampu mempercepat karyawannya dalam memenuhi kriteria sebuah posisi. Pengembangan yang baik merupakan pengembangan yang mampu selaras baik kebutuhan saat ini maupun kebutuhan dimasa yang akan datang. Menurut para SE dan LM, Unilever sudah cukup selaras antara program TM dan strategi bisnis dimasa yang akan datang. Era digital dan social media sudah diperkenalkan dan dipersiapkan dengan baik 
akan tetapi masih harus ada perbaikan. Hal ini sejalan dengan pernyataan Campbell dan Hirsh (2013) bahwa TM begitu tinggi dalam agenda perusahaan dan akan menjadi efektif apabila tujuannya selaras dengan strategi bisnis organisasi.

\section{Penilaian untuk Menciptakan Pemimpin Masa Depan}

Perusahaan percaya orientasi kerja nyata akan membuahkan hasil yang lebih baik sebagai pelajaran bagi karyawan, dengan menerapkan konsep $70 \%$ tugas berbasis kerja (experience atau on the job assignment), 20\% relationships atau mentoring serta $10 \%$ formal development. Faktor-faktor yang dijadikan sebagai dasar penilaian yaitu:

1. Keterampilan. Keterampilan inti mendukung dalam keunggulan fungsional. Keterampilan yang dimiliki harus sesuai dengan keterampilan umum sebagai seorang profesional.

2. Tindakan, yang berkaitan dengan keterampilan yang dibutuhkan sebagai seorang pemimpin memenuhi SoL (Standard of Leadership).

3. Pengalaman untuk mengembangkan pengetahuan dan pemahaman yang luas tentang bisnis. Sehingga mampu memberikan perspektif dan kemampuan untuk melihat gambaran yang lebih besar dalam situasi bisnis yang kompleks

4. Kinerja, yang berkaitan dengan konsistensi pencapaian dan rekam jejak kinerja yang akan terbukti sangat penting untuk menjadi profesional atau yang disebut JDI (Judgement Drive Individual).

Alat penilaian yang digunakan dalam melakukan penilaian karyawan diantaranya:

1. Penilaian 360 derajat, penilaian ini setidaknya dilakukan setiap satu tahun dua kali, yang dilakukan di tengah dan akhir tahun, yang dilakukan sekaligus dengan penilaian. Meski begitu, diskusi dapat dilakukan kapan saja, disesuaikan dengan kebutuhan para karyawan.

2. SoL (Standard of Leadership)

- Growth Mindset yaitu kepemimpinan yang kompetitif yang merupakan sikap yang positif serta realistis mengenai masa depan perusahaan.

- Consumer and Costumer Focus yaitu kepemimpimpan yang didorong oleh sebuah tujuan yaitu pada konsumen dan pelanggan. Sikap ini berusaha untuk melihat brand atau merek dari mata konsumen.

- Bias for Action yaitu kepemimpinan yang mengedepankan tindakan. Hal ini akan menunjukkan sense of urgency dalam pengambilan keputusan, yang menunjukkan tindakan teranalisa dan pengambilan risiko yang cerdas.

- Accountability and Responsibility yaitu kepemimpinan yang mengutamakan prestasi. Sikap ini harus bisa menunjukkan kepunyaan terhadap prestasi perusahaan Unilever secara keseluruhan.

- Building Talents and Team yaitu kepemimpinan yang berorientasi pada orang. Hal ini berkaitan dengan berinvestasi pada pengembangan orang. Sikap ini juga membangun tim yang bersatu untuk menang.

3. Individual Development Plan (IDP), merupakan rencana pengembangan baik itu karakter, kemampuan, komitmen, maupun harapan dari karyawan yang harus diisi secara online. IDP terdiri dari jangka pendek, menengah dan panjang.

4. Judgment, Drive and Influence (JDI), model penilaian yang dikembangkan oleh YSC (Young, Samuel, Chamber) yang digunakan untuk membantu, menjelaskan, identifikasi dan mengembangkan kemampuan leadership seseorang. Berdasarkan hasil observasi 
Ahmad Saomin Ali

Aji Hermawan

Yudha Heryawan Asnawi

aplikasi yang dilakukan di PT Unilever Indonesia Tbk, penilaian digunakan untuk menilai para karyawan pada tahap awal akan bergabung ke dalam program TM.

5. Key Performance Indicators (KPI) atau $3+1$. Penilaian $3+1$ ini dilakukan di akhir tahun, dan akan didiskusikan dengan karyawan terkait pencapaiannya setiap semester, sehingga pencapaian dari target tetap termonitor dengan baik.

\section{Strategi Talent Management atau People Branding}

Strategi TM yang digunakan PT Unilever Indonesia Tbk meliputi attracting, developing dan retaining (Gambar 2).

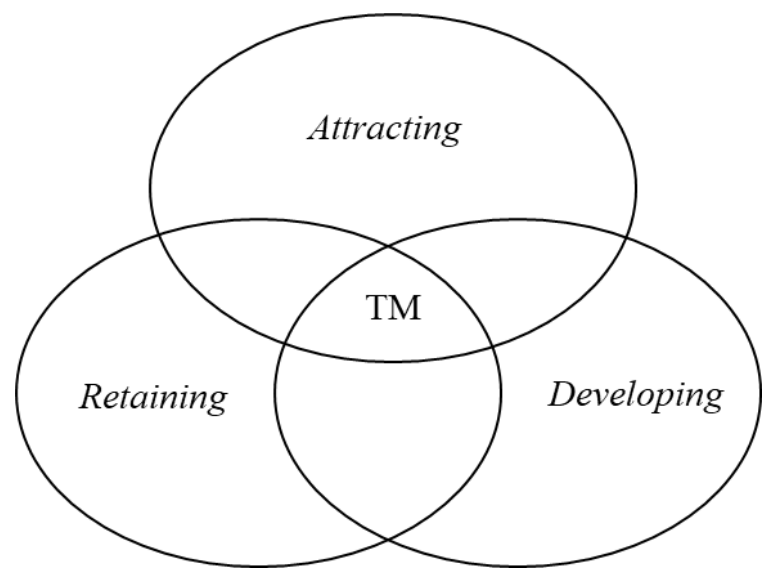

Gambar 2.

Strategi Talent Management PT Unilever Indonesia Tbk

Attracting yaitu langkah awal untuk mengetahui kebutuhan talent dan memahami kompetensi apa yang harus dimiliki oleh seorang karyawan. Salah satu langkah yang dilakukan perusahaan yaitu melakukan rekrutmen baik itu internal (promosi) maupun eksternal (employer branding). Berdasarkan wawancara dengan LM 1 bahwa seleksi talent saat ini sudah baik. Beberapa alasan para peserta TM bergabung dengan Unilever adalah terkait dengan benefit, karir, brand, image, reputation, work life balance, mobilitas atau pergerakan yang cepat, program pengembangan, manajemen yang baik meliputi visi dan misi yang jelas, dan pertumbuhan perusahaan yang baik. Menurut Thrift (2012) perlu adanya strategi yang tinggi dalam merekrut serta adanya perilaku keterlibatan tinggi dalam upaya menarik karyawan ke dalam organisasi. Sedangkan menurut Horner-Smith (2014) praktik perekrutan menekankan pada standar perekrutan untuk meningkatkan kinerja dan daya saing. PT Unilever Indonesia Tbk memiliki standar yang tinggi pada perekrutan atau penarikan para talent. Hal ini dimaksudkan agar karyawan mampu mencapai kinerja yang baik dan memiliki daya saing. Hal ini sebagai strategi perusahaan dalam menghadapi era globalisasi dan teknologi. Diharapkan dengan perekrutan atau penarikan para talent baik itu dari eksternal meliputi lulusan baru dan profesional maupun internal memiliki kemampuan yang mumpuni dalam menghadapi tantangan bisnis di masa yang akan datang.

Developing, Supply Chain Academy diperkenalkan sebagai bentuk bukti nyata dari perusahaan dalam mengembangkan karyawan. Pengembangan saat ini yang digunakan oleh Unilever diantaranya classroom, e-learning, coaching dan mentoring, on the jo training, job enrichment, dan job enlargment. Penemuan ini didukung oleh Thrift (2012) yang menyatakan bahwa program pengembangan berdasarkan rotasi pekerjaan dan penambahan pekerjaan atau proyek merupakan elemen penting dari strategi TM. Program ini merupakan cara berharga untuk mengembangkan kandidat dalam memperoleh pengetahuan dan perspektif bisnis yang berbeda akan tetapi harus ditunjang dengan desain kurikulum yang menguraikan peran dan tanggung jawab dan harapan dari semua anggota yang terlibat. Thrift menemukan juga bahwa peserta TM tidak mengetahui dengan jelas apa 


\section{Jurnal Manajemen Teori dan Terapan Tahun 12. No.1, April 2019}

peran baru saat di rotasi. Penelitian tersebut juga mengungkapkan bahwa tidak selamanya peserta mendapatkan keterampilan yang lebih banyak pada saat di rotasi, sehingga pada saat di rotasi perlunya seorang mentor. Peran mentor sangat penting, serta desain program rotasi yang jelas mengartikulasikan harapan dan peran dari hosting yang terlibat. Hal ini memungkinkan para peserta untuk dengan cepat beralih ke peran baru mereka dan meminimalkan hilangnya waktu mencoba untuk mencari tahu peran baru mereka.

Temuan yang sama bahwa rotasi yang terjadi saat ini terlalu cepat sehingga para karyawan belum mendapatkan ilmu yang mendalam untuk posisi tersebut. Rotasi memang sangat baik untuk seorang karyawan, tapi seharusnya dengan adanya rotasi harus memberikan dampak yang positif untuk karyawan. Perusahaan harus mampu mendorong seluruh karyawan untuk mampu memiliki kompetensi yang baik, sehingga rotasi tidak hanya terpaku pada satu orang yang dianggap paling mumpuni pada segala bidang. Kemungkinan yang terjadi adalah perlunya karyawan yang kompeten pada posisi tersebut, sehingga rotasi terjadi atau memang rotasi diperlukan sebagai strategi dari perusahaan untuk mencapai kinerja perusahaan yang optimal.

Retaining, semakin memahami kebutuhan karyawan maka semakin erat terjalin employee retention. Perusahaan berharap profesional SDM mampu mempertahankan karyawan demi pertumbuhan dan kemajuan perusahaan dimasa mendatang dengan keunggulan yang kompetitif. Perusahaan yang melakukan pekerjaan terbaik dalam mengelola talent, terbukti memberikan hasil yang jauh lebih baik bagi perusahaan (Oladapo, 2014). Perusahaan yang mampu melakukan praktik TM dengan benar akan memberikan kinerja yang luar biasa. Menurut Axelord, Jones dan Welsh (2001) TM memang bukan satu-satunya penggerak untuk kinerja seperti itu, tetapi TM jelas sangat berpengaruh. Cara-cara untuk mempertahankan karyawan adalah membawa culture yang lebih menantang, budaya lebih terbuka, apresiasi berupa acknowledgment dan contribution, dan team work (LM 2). Hasil observasi $57 \%$ untuk manufacture dan $75 \%$ non-manufacture menunjukkan bahwa alasan meninggalkan perusahaan adalah karir yang lebih baik. Penelitian Oladapo (2014) menemukan bahwa ada tiga alasan utama yang diberikan responden dalam meninggalkan organisasi yaitu peluang untuk lebih baik, keamanan kerja dan kompensasi.

TM dan HRM adalah dua hal yang berbeda. Berdasarkan hasil observasi secara konsep TM adalah sesuatu hal yang baru yang tidak dapat dibandingkan dengan HRM. Praktik TM terkonsep mulai dari penarikan, pengembangan dan mempertahankan talent. TM merupakan bagian dari HRM, akan tetapi keduanya merupakan hal yang berbeda. TM di Unilever sangat kental dengan pengembangan karyawan. Keinginan karyawan dapat diketahui melalui Individual Development Plan (IDP). Semua karyawan diberikan kesempatan untuk berkembangan sesuai dengan keinginannya. Hal ini sejalan dengan yang disampaikan oleh Chuai (2008) yang membandingkan antara HRM dengan TM dalam hal literatur dan temuan empiris. Chuai menemukan bahwa TM memberikan beberapa pendekatan baru dan berbeda untuk manajemen SDM dalam organisasi daripada pengemasan ulang teknik dan ide lama dengan label baru.

Hal ini sesuai dengan Ashton dan Morton (2005) yang menyatakan bahwa TM lebih dari sekedar bahasa baru untuk pekerjaan SDM lama. Sehingga menurut Chuai TM tidak boleh dianggap sebagai "old wine in new bottles". Chuai melihat TM sebagai ideologi manajemen baru yang dapat membuat perbedaan bagi keberhasilan dan keunggulan kompetitif organisasi dengan mempertimbangkan fakta bahwa kemunculan dan penerapannya secara fundamental sesuai dengan tuntutan perusahaan untuk pengembangan lebih lanjut dan secara erat digabungkan dengan strategi bisnis. Cooke, Saini dan Wang (2014) dalam penelitiannya menunjukkan bahwa lebih dari $70 \%$ respondennya melaporkan bahwa perusahaan mereka tidak memiliki skema khusus TM. Mayoritas menyatakan bahwa tidak diperlukan skema TM yang terpisah, sehingga TM dilakukan melalui kebijakan dan praktik HRM. Menurut Cooke, Saini dan Wang (2014) hal ini menunjukkan kurangnya perbedaan antara HRM secara umum dan TM khusus dari perspektif responden. 


\section{Ahmad Saomin Ali \\ Aji Hermawan \\ Yudha Heryawan Asnawi}

Berdasarkan hasil wawancara, HR dan SE menyatakan bahwa TM berbeda dengan HRM. Selain itu, perlu konsistensi dan dukungan yang besar dari semua pihak terutama dari senior eksekutif dan level diatasnya dalam menjalankan TM. TM yang saat ini berjalan tidak dapat terpisahkan dari kegiatan sehari-hari. TM tidak memiliki agenda khusus akan tetapi menjadi bagian satu kesatuan dengan kegiatan para peserta. Hal ini sejalan dengan penelitian yang dilakukan oleh Chuai (2008) menemukan bahwa konsep TM merupakan serangkaian praktik untuk memastikan fungsi-fungsi yang berbeda saling terkait satu sama lain.

\section{Tantangan dan Hambatan dalam Implementasi Talent Management}

Berdasarkan hasil penelitian yang dilakukan, tantangan dan hambatan yang dihadapi dalam implementasi TM di PT Unilever Indonesia Tbk diklasifikasikan dalam dua level yaitu level organisasi dan individu (Tabel 3).

Tabel 3.

Tantangan dan hambatan dalam Impelementasi Talent Management di PT Unilever Indonesia Tbk

\begin{tabular}{|c|c|}
\hline Level & Tantangan dan hambatan \\
\hline Organisasi & $\begin{array}{l}\text { A. Masalah Sistem Program TM } \\
\text { - Program TM tidak memiliki target waktu. } \\
\text { - Kurangnya program yang mampu menarik } \\
\text { keinginan karyawan untuk lebih baik dalam } \\
\text { sistem pembelajaran yang telah disediakan. } \\
\text { B. Sistem karir yang tersendat } \\
\text { C. Masalah dengan faktor push dan pull } \\
\text { - Faktor push } \\
\text { - Faktor pull }\end{array}$ \\
\hline Individu & $\begin{array}{l}\text { A. Masalah Kompetensi } \\
\text { B. Keterbatasan Waktu } \\
\text { C. Adaptasi }\end{array}$ \\
\hline
\end{tabular}

Banyaknya hambatan yang dihadapi tergantung dari jenis perusahaan atau jenis sampel penelitian yang digunakan, serta konsistensi atau eksistensi perusahaan dalam berfokus menjalankan TM. Tafti, Mahmoudsalehi, dan Amiri (2016) menjelaskan bahwa jenis perusahaan yang digunakan penelitian adalah industri otomotif dengan populasi meliputi manajer, spesialis dan ahli dari bagian SDM di industri otomotif, akan tetapi hal yang ditemukan ada banyak kemiripan. Collings dan Mellahi at al. (2010) dengan sampel perusahaan multinasional menunjukkan bahwa banyaknya turnover di perusahaan peneliti diakibatkan perencanaan karir yang belum baik. Cooke at al. (2014) membandingkan implementasi TM di dua negara yaitu China dan India. Cooke at al. kesamaan bahwa karyawan menginginkan perencanaan karir yang jelas sehingga hal tersebut mampu membuat mereka bertahan lebih lama di perusahaan. Berdasarkan hasil wawancara yang dilakukan, terdapat beberapa masukan yang disampaikan oleh para pemangku kepentingan dan para peserta untuk memperbaiki program TM. Masukan-masukan tersebut diantaranya review kondisi organisasi atau struktur organisasi, perjalanan karir yang jelas, lingkungan pekerjaan, paket remunerasi dan kompensasi, memperbaiki peran dan struktur dari tim SDM, monitoring program yang lebih baik, alokasi waktu, kemampuan memahami kebutuhan setiap peserta TM dan kesempatan berkembang yang lebih terbuka untuk semua karyawan.

\section{SIMPULAN}

Temuan dalam penelitian ini menunjukkan bahwa pemahaman pada konsep TM memiliki perbedaan yang berbeda pada setiap level baik itu pemangku kepentingan (profesional SDM, senior eksekutif dan line manajer) maupun peserta, pemangku kepentingan terutama profesional SDM lebih memahami terkait TM, sedangkan senior eksekutif melihat 
bagaimana TM ini berhubungan dengan strategi bisnis dan line manager lebih memahami pada bagaimana TM ini berjalan dengan baik sedangkan peserta TM memahami bagaimana kondisi TM yang saat ini sedang berjalan. Praktik TM di PT Unilever Indonesia Tbk menggunakan pendekatan inclusive people. Praktik TM sudah cukup baik akan tetapi masih harus ada perbaikan dan praktik TM saat ini menekankan pada tugas berbasis kerja nyata (experience atau on the job assignment) sebesar $70 \%$, ditunjang dengan coaching dan mentoring (20\%) serta $10 \%$ formal development. Tantangan dan hambatan yang saat ini dihadapi dalam implemetasi TM diklasifikasikan ke dalam dua tingkatan yaitu organisasi dan individu. Organisasi meliputi masalah sistem program TM (program TM tidak memiliki target waktu dan kurangnya program yang mampu menarik keinginan karyawan untuk lebih baik dalam sistem pembelajaran yang telah disediakan), sistem karir yang tersendat, masalah dengan faktor pull dan push. Sedangkan tingkatan individu terdiri masalah kompetensi, keterbatasan waktu dan masalah adaptasi. Hambatan yang dihadapi dalam implementasi TM akan berbeda untuk setiap perusahaan yang tergantung kepada sejauh mana implementasi dan komitmen dalam menjalankan TM.

\section{DAFTAR PUSTAKA}

Ashton, C., \& Morton, L. 2005. Managing Talent For Competitive Advantage: Taking A Systematic Approach To Talent Management. Strategic HR Review. 4(5):28-31. http://dx.doi.org/10.1108/14754390580000819.

Axelord, E.L., Jones, H.H., \& Welsh, T.A. 2001. War for talent. McKinsey Quarterly. (2):9-11.

Baum, M., \& Kabst, R. 2013. How to Attract Applicants in The Atlantic Versus the Asia-Pacific Region? A Cross-National Analysis on China, India, Germany, and Hungary. Journal of World Business. 48 (2013):175-185. http://dx.doi.org/10.1016/j.jwb.2012.07.002.

Campbell, V., \& Hirsh, W. 2013. Talent Management A Four-Step Approach [ulasan]. Institut For Employment Studies. 502.

Cappelli, P., \& Keller, J.R. 2014. Talent Management: Conceptual Approaches And Practical Challenges. Journal of Annu. Rev. Organ. Psychol. Organ. Behav.1:305-31. https:// doi: 10.1146/annurev-orgpsych-031413-091314.

Chen, Y.M. 2015. How Do National and Organizational Cultures Affect Talent Retention During an International Merger and Acquisition? [disertasi]. Minneapolis: Capella University.

Chuai, X. 2008. Is Talent Management Just Old Wine In New Bottles?: The Case Of Multinational Corporations In Beijing [disertasi]. Middlesbrough: University of Teeside.

Chuai, X., Preece, D., \& lles, P. 2008. Is Talent Management Just "Old Wine In New Bottles"? The Case Of Multinational Companies In Beijing. Management Research News. 31(12):901-911. https://doi:10.1108/014091708109260611.

Collings, D.G. 2014. Integrating Global Mobility And Global Talent Management: Exploring The Challenges and strategic opportunities. Journal of World Business. 49: 253-261. http://dx.doi.org/10.1016/j.jwb.2013.11.009.

Collings, D.G., \& Mellahi, K. 2009. Strategi Talent Management: A Review And Research Agenda. Human Resource Management Review.19(4):304-313. http://dx.doi. org/10.1016/j.hrmr.2009.04.001.

Cooke, F.L., Saini, D.S., \& Wang, J. 2014. Talent Management In China And India: A Comparison Of Management Perceptions And Human Resource Practices. Journal of World Business. 49:225-235. http://dx.doi.org/10.1016/j.jwb.2013.11.006.

Davis Tony ,Maggie cutt,neil flynn(2007) Talent assessment, a new strategy for talent management .Gower,United States.Retrived on 22 march 2013. 
Ahmad Saomin Ali

Aji Hermawan

Yudha Heryawan Asnawi

Divakaran, A., Mani, M., \& Post, L. 2012. Best Practice For Meeting Manufacturing's Global Talent Challenge. Ivey Business Journal.

Doran, C., \& Littrell, R. 2013. Measuring Mainstream US Cultural Values. Journal of Business Ethics. 117(2):261-280. DOI:10.1007/s10551-012-1515-z.

Falmholtz, E.G., \& Randle, Y. 2012. Corporate Culture, Business, Models, Competitive Advantage, Strategic Assets and The Bottom Line. Theoritical and Measurement Issues. Journal of Human Resource Costing\&Accounting. 16(2):76-94. doi:10.1108/14013381211284227.

Fey, C.F. and Denison, D.R. 2003. Organisational Culture and Effectiveness, Can American Theory be Applied in Russia. Organisation Science, 14(6):686-706.https,//doi. org/10.1287/orsc.14.6.686.24868.

Herdiansyah, H. 2010. Metodologi Penelitian Kualittaif Untuk IImu-IImu Sosial. Cetakan ke-3. Jakarta: Penerbit Salemba Humanika.

Horner-Smith, M.J. 2014. Human Resource Executives' Perceptions Of Talent Management And The Influence Of Transformational Leadership Style On Their Perceptions Of Hiring Practices [disertasi]. Minneapolis: Capella University.

Idowu, O.E. 2017. Understanding Organisational Culture and Organisational Performance: Are They Two Sides of The Same Coin?. Journal of Management Research. 9(1). doi:10.5296/jmr.v9i1.10261.

lles, P., Chuai, X, \& Preece, D. 2010. Talent Management And HRM In Multinational Companies In Beijing: Definitions, Differences And Drivers. Journal of World Business. 45(2):179-189. https://doi:10.1016/j.jwb.2009.09.014.

Kabwe, C.B. 2011. The Conceptualisation And Operationalisation Of Talent Management: The Case Of European Internationally Operating Business [disertasi]. Preston: University of Central Lancashire.

Lee, S.K.J., \& YU K. 2004. Corporate Culture and Organizational Performance. Journal of Managerial Psychology. 19(4):340-359.doi:10.1108/02683940410537927.

Lewis, R.E., \& Heckman, R.J. 2006. Talent Management: A Critical Review. Elsevier Human Resource Management Review. 16:139-154.

McDonnell, A., Lamare, R., Gunnigle, P., \& Lavelle, J. 2010. Developing Tomorrow's Leaders - Evidence Of Global Talent Management in multinational enterprises. Journal of World Business. 45:150-160. https://doi:10.1016/j.jwb.2009.09.015.

Mellahi, K., \& Collings, D. G. 2010. The barriers to effective global Talent Management: the example of corporate elites in MNEs. Journal World of Business. 45: 143-149. https:// doi:10.1016/j.jwb.2009.09.018.

Morissan. 2014. Metode Penelitian Survei. Cetakan ke-2. Jakarta: Penerbit Kencana Prenadamedia Group.

Oladapo, V. 2014. The Impact Of Talent Management On Retention. Journal of Business Studies Quarterly. 5(3):2512-1034.

Preece, D., lles, P., \& Chuai, X. 2011 . Talent Management And Management Fashion In Chinese Enterprises: Exploring Case Studies In Beijing. The International Journal of Human ResourceManagement. 22(16):3413-3428.https://doi:10.1080/09585192.2011.586870.

Savaneviciene, A., \& Vilciaukaite, B. 2017. Practical Application Of Exclusive And Inclusive Talent Management Strategy In Company. Business, Management and Education. 15(2):242-260. https://doi:10.3846/bme.2017.366.

Silzer, R., \& Dowell, B.E. 2009. Strategy-Driven Talent Management: A Leadership Imperative [e-book]. Pfeiffer. [diunduh 2018 Nov 28]. Tersedia pada: https://bit.ly/2F3Tgz2. 
Staunton, M. 2014. Implementing Talent Management in a global services company [disertasi]. Portsmouth: University of Portsmouth Business School.

Swailes, S., Downs, Y., \& Orr, K. 2014. Conceptualising Inclusive Talent Management: Potential, Possibilities And Practicalities. Human Resource Development International. https:// doi:10.1080/13678868.2014.954188.

Tafti MM, Mahmoudsalehi M, Amiri M. 2016. Critical Success Factors, Challenges And Obstacles In Talent Management. Emerald Publishing Limited Industrial and Commmercial Training. 59(1):15-21. https://doi:10.1108/ICT-05-2016-0036.

Tansley, C. (2011),"What do we mean by the term "talent" in talent management?", Industrial and Commercial Training, Vol. 43 Iss: 5 pp. 266-274.

Tarique, I., \& Schuler, R.S. 2009. Global Talent Management: Literature review, Integrative Framework, And Suggestions For FURTHER Research. Journal of World Business 45:122133. https://doi:10.1016/j.jwb.2009.09.019.

Thrift, J. 2012. An Examination Of Talent Management Strategies For A Large Investor-Owned Utility Company: Facing The Market Pressure Of The $21^{\text {st }}$ Century [disertasi]. Malibu: Pepperdine University.

Wilson, M.D. 2015. A Qualitative Case Study Of The Talent Management Process Across Project-Oriented Companies Within The Intellect Industry [disertasi]. Mineapollis: Capella University. 